Pregledni članak

Review Paper

UDC: $792.075: 658.14: 1 \mathrm{e}(673)$

DOI : dx.doi.org/10.12803/SJSECO.48160

JEL: M0, M13

\title{
DETERMINANTS OF SMALL ENTERPRISE FAILURE IN ANGOLA: A MANAGERIAL AND FINANCIAL PERSPECTIVE
}

\author{
Determinante neuspeba malib preduzeća u Angoli: menadžerska \\ i finansijska perspektiva ${ }^{\nabla}$
}

Mateus Vicente Justino

Faculty of Business, Cape Peninsula University of Technology, Cape Town, South Africa

Robertson K. Tengeh

Faculty of Business, Cape Peninsula University of Technology, Cape Town, South Africa

\begin{abstract}
It is well established that a number of factors contribute disproportionately to the failure of Micro and Small Enterprises (MSEs) in most economies. This paperexamined the contribution of managerial and financial factors to the failure of MSEs in the context of Angola.Thepaper adopted a positivist theoretical perspective, by utilizing thequestionnaire as the primary data collection instrument within the quantitative research technique. Data was collectedfrom108 small business owners and managers with business failure experiences, approached through snowballing sampling technique.The data was analysed with the aid of the Statistical Package for the Social Sciences (SPSS) program. The results ascertain that, insufficient knowledge in the domain of businesssystems, insufficient skills in the domain of financial accounting and negligence to plan and control business resources, by the small business owners and managerswere among the factors that contributed to small enterprise failure in Angola. Thisreportsthe lack ofinstitutions actively in promotingentrepreneurshipfor knowledge and skills development andthe absence of successful entrepreneurial role models, business mentors or coaches for entrepreneurial capacity building.
\end{abstract}

Keywords: small business failure, failure factor, business environment, entrepreneur, Angola

\footnotetext{
$\nabla$ Kontakt autora: tengehr@cput.ac.za. Autori izjavljuju da nemaju značajne materijalne ili finansijske interese koji se odnose na istraživanje opisano u ovom radu. Takođe, autori izjavljuju da je podneti članak njihov originalan rad i da nakon izdavanja ništa od sadržine neće predstavljati povredu autorskog prava. Rad primljen 29.09.2015. godine. Odobren za objavljivanje 10.11.2015. godine. The authors declare that they bave no relevant or material financial interests that relate to the research described in this paper. Also, the authors declare that the submitted paper is their original work and that, upon publication, notbing contained in it will not constitute an infringement of any copyright. Paper received 29.09.2015. Approved 10.11.2015.
} 


\section{Introduction}

Small and Medium sizes Enterprises (MSEs) are well recognised for their perceived potential to contribute to job creation, poverty alleviation, and economic growth (Mead \& Liedholm, 1998; Ihua, 2009; Singh \& Belwal, 2008; Nichter \& Goldmark, 2009; Cant \& Wiid, 2013). Even so, some authors contest that MSEs are not the fountainhead of job creation (Davis, Haltiwanger \& Schuh, 1994). Although the latter may hold true, the current literature continues to sing the praises of MSEsespecially in the countries championing the debate. For instance, in Australia, MSEs accounted for 47.2 \% of employment between 2009 and 2010 (Clark, Eaton, Lind, Pye \& Bateman, 2011).Turning to Africa, evidence from five developing countries; Botswana, Kenya, Malawi, Swaziland, and Zimbabwe, concluded that about one third of all new jobs in these countries were created by MSEs (Mead \& Liedholm, 1998).

Considering the above positive effects that small businesses have onaneconomy, it goes without saying that the failure of MSEs and its aftereffects will not be encouraged (Di Pietro \& Sawhney, 1977; Altman, 1984). Hence, countries across the world continuously seek new and innovate ways of improving the performance and success rate of businesses (Holt, 2013). This notwithstanding, the persistence of a considerably high rate of businesses failure in Angola,providedthe impetus for this paper. Though often overstated, it is believed that the failure rate peaked at $96.7 \%$ at one time (Angola Press Agency (Angop), 2013; Angonotícias, 2013; Dias, 2013), and this is significantly high when compared to other countries.

In the effort to curb the rate of business failure, the Angolan government initiated a number of programs. Some of the noteworthy measures included the inclusion of entrepreneurship in the curricula of secondary schoolsin 2009 (Mendes, 2012), the "Angola Investe" program, with the mission to promote the development and consolidation of MSMEs (Angola, MINEC, 2013), and the so called One-stop Shop program for Entrepreneurs (BUE) implemented in 2012(Angola, Diário da República, 2012).

Howbeit the manybusiness support programs, a high failure rate persists.In fact aGlobal Entrepreneurship Monitor (GEM) report indicates that in 2008, Angola had the highest rate of business failure (23.4\%) (Bosma, Acs, Autio, Coduras \& Levie, 2009), and in 2013, Angola had the highest rate of business failure (24.1\%), compared with the South African rate of $4.9 \%$, Ghana $8.3 \%$ and Nigeria $7.9 \%$ (Amorós \& Bosma, 2014).On the one hand,Zinga, Coelho and Carvalho (2013) believe that lack of business education and training in Angola has minimised the probability of many entrepreneurs acquiring the necessary management skills to sustain their enterprises. On the other hand, Da Rocha (2011); Mendes (2012); and Herrington (2014) note that another prominent contributor to business failure in Angola could be associated with the mass exodus of skilled people and probable entrepreneurial role models during the civil war. And to some extent, the lack of appropriateinfrastructurecan be attributed the war (Mendes, 2012). 
Notwithstanding the just mentioned factors associated with business failure in Angola, Herrington (2014) notes that further investigation is necessary. Following Herrington's (2014) urge, and the fact that a seemingly unlimited number of factors are associated with business failure, this paper investigated the specific role that managerial competence and financial skillsplay in the process, with specific reference to Angola.

\section{Literature review}

According to Greener (2008), a literature review should provide an in-depth discussion of the subject matter of a study. In agreement, Yin (2011) and Bhattacherjee (2012) declare that the primary purpose of a literature review is to focus on the central idea of the asserted topic, method, and sources of data, identifying theories and findings related to the topic of study and the gaps to be filled.Accordingly, this section sort to identify the gap in the literature with regards to the managerial and financial factors that contribute to the failure of small businesses. This section is structured into two main themes: theoretical overview of small business failure andthe failure factor overview.

\subsection{Theoretical overviewof small business failure}

A theory refers to a series of assorted concepts thatattempt to defend the rationality of an idea (Marvasti, 2004). The theory's main idea can be represented by a single hypothesis or by a sequence of hypotheses that explain an event that has been studied (Yin, 2011). In the context of this study, the event refers to the failure of small businesses.

Nemaenzhe (2010) defines small business failure as any small business that freely closes or is forced to, because either the owner's lawful right has been lost or it is no more profitable. Dasgupta and Sanyal (2010) argue that a small business failure rises in a gradual sequence of small particles of failures to a final failure. The preceding statements, suggests that small business failure is an event that can be avoided, and that managers can equip themselves with the necessary tools to mitigate most risks associated with businesses. This statement is supported by Tengeh (2011), who relays a number of factors that are related to business failure such as;lack of business knowledge, lack of capital, less market share, and so forth that can be overcome with the entrepreneur's positive attitude to success and minimum effort. Additionally, Hendrikse and Hendrikse (2004) maintain that although the best practice of business procedure is not a guaranteed formula for success, it nonetheless reduces the risks of business failure significantly.

\subsubsection{The Hazard modelsas postulates of failure factor}

The Hazard models, also known as Cox regression models, are widely used to examine business's failure. The models were developed by Cox (1972) and first applied 
in the fields of medicine and engineering to analyse the interval between the surviving or not surviving of patients and the period to failure of materials (Lane, Looney \& Wansley, 1986; Molina, 2002).

Subsequently, the Hazard models were adapted and utilised in business studies to resolve a number of issues such as determining the factors that cause small business failure, and to predict the likely hood of failures (Lane, et al., 1986; Honjo, 2000; Shumway, 2001; Molina, 2002; Bhattacherjee, 2005). According to Bhattacherjee (2005), a notable advantage of the hazard model is the ability to predict the occurrence of an event while allowing the observer to isolate the effects of other varaibles.

Notwithstanding the strong support for the Hazards models, anumber of authors argued against its applicability due to its high reliance on assumptions, particularly with regards to the explanatory risk factors, added to separate the effects of age and determining conditional hazard rates (Bhattacherjee, 2005; Preisendorfer \& Voss, 1990; Shumway, 2001). Notably, the models do not provide further descriptive details of the failure factors.In the context of this paper, the modelsprovide valuable insights into an understanding of the changes and challenges in the business environment. The next model to be reviewed will be Nemaenzhe's small business failure process model.

\subsubsection{Nemaenzhe's small business failure process model}

The proposed small business failure process model by Nemaenzhe (2010) was included in this review because of its most compelling similarity to the nature of this study. The Nemaenzhe model outlines a sequence of three-step events, emphasising resources and opportunities thatcombined, influence the success or failure of a business. The first step defends that poor business management results in inefficiencies that cause the small business to fail internally, mainly because of inappropriate mixture or imbalance of resources and opportunities, and the effect of environmental uncertainties (Nemaenzhe, 2010). Many authors, including Di Pietro and Sawhney (1977); Altman and Narayanan (1997); Khalfan (2003); Pratten (2004); Ooghe and Prijcker (2008); and Mahamid (2012), hold a similar viewwith regardsincompetent management as a factor that causes a number of businesses to fail.

The second step highlights that combining resources and opportunities, at different levels (for instance, if both are lower)may lead to business failure, due to the manager's inability to manage them. In contrast, combining resources and opportunities at a higher level will have a positive effect on the business. To clarify the above statements, the resources concerned, relate to financial, human, physical, information resources and so forth(Nieman \&Nieuwenhuizen, 2009). And the opportunities, involved may include those emanating from the business environmental factors which may facilitate the creation or development of new products, meeting new customers, innovation, etc.

The third phasenotes a combination of four failure factors (i.e. monitoring and control, experience and planning, income constraints, and cash control), influenced by 
environmental factors which if not efficiently managed may lead to the final failure of the small business (Nemaenzhe, 2010).

\subsection{An overview of failure factors}

Identifying the factors causative of business failures is essential, as it may enable MSEsto reduce the probability of failure in the future and provide the impetus for effective policy initiatives (Di Pietro \& Sawhney, 1977; Khalfan, 2003). Though this may sound straightforward, Holt (2013) warns that the failure of a business is a "complex phenomenon" with a variety of factors associated with it. Yeo (2002) defines failure factors as obstructive issues that may arise from the business environment and impact negatively on the performance of a business. These obstructive issues may vary from economy to economy, mainly due to differencesin the economic condition, political and social environment of the host country (Arasti, 2011). For example, a survey that examined the MSEs key failure factors in both the United Kingdom (UK) and Nigeria, found "poor management" to be a critical factor in the UK, and "poor economic conditions and infrastructural inadequacy" to be the critical factors in Nigeria (Ihua, 2009).Similarly, a study conducted by Ooghe and Prijcker (2008) in Belgium, found push factors such as, lack of competitive advantage, non-satisfied customers, and suppliers and banks losing trust to be more prominent with regards to causes of business failure.

However, in the Angolan context, the factors associated with business failure can be within the control of the owner/managers and those beyond their span of control. Highlighting the impact and scale of the latter, one would argue that the unstable political, economic and social environment generated by the civil war had a significant impact on MSEs.Cronje, Du Toit, Marais, and Motlatla (2004),concur that businesses are highly dependent on the inputs of both internal and external elements, which can influence their success or failure. The latter argument is further supported by Strydom (2011) and Tengeh (2011) who maintain that, the factors that impact a business's viability can be endogenous and exogenous.

\subsubsection{The entrepreneur}

Nieman and Nieuwenhuizen (2009) see an entrepreneur as an individual who starts a business.He is characterised as the person who possesses a drive for business creation; find a gap in the market, assembles the necessary business licensing and permits, financial resource, equipment, human resources and sets up a business to fill the gap (Barringer \& Ireland, 2010).

Cronjeet al. (2004)argue that the success or failure of the business is greatly influenced by the entrepreneur or manager's own strategic approach to running the business. Correspondingly, Hendrikse and Hendrikse (2004) assert that an entrepreneur with a positive mind-set strives to acquire the skills to achieve goals, and this can significantly reduce the chances of business failure. This statement is supported by 
Nieman and Nieuwenhuizen's (2009) assertion that the lack of a positive attitude towards success underpins the failure of most small businesses. For example, it is through an entrepreneur's strategic decisions that he/she influences the market environment positive or negative (Cronje et al., 2004). Such strategic approaches include how the management integrates the business' objectives, decide, solve the problems, conserve the image of the business, or deal with the market environment (Cronje, et al., 2004).

It may be concluded that, whensuccess is one of an entrepreneurs'goals, as it is the case for all entrepreneurs, there is a need to acquire all the necessary technical skillsto reach such goals.Hence, the entrepreneur or manager becomes the primary main player in the business, tasked with the responsibility of making a success of a business (Barringer \& Ireland, 2010).

\subsubsection{Management Skills Factors}

Management skills refer to the managers' planning skills, organising skills, leading skills, and controlling skills pertaining to the functionalities of the business (Nieman \& Nieuwenhuizen, 2009). Similarly, Strydom (2011) sees management skills as "conceptual, human and technical skills that allow managers to fulfil their management tasks." According to Arasti (2011), many of the factors that may cause business failure are inherently linked to management's approachto the resolution of problems, and "deficiencies" in acquiringand utilisation of "technical and management skills". In addition, Mahadea and Youngleson (2013) claim that lack of effective leadership; general management skills; financial and market planning are pertinent factors to be considered. According to Cronje, du Toit and Motlatla (2000) planning gives rise to other management tasks, such as organising, implementing, leading and control. Therefore, without planning the other steps in management cannot be taken effectively.However, since many small businesses operate on a basis of sole-decisionmaking, one can say that the entrepreneur/manager becomes the most important element in the operation of the business, and poor management performance is fatal. This latter view issupported by Mahamid (2012), who found thatmost small businesses failed because managers lack understanding of the business system, lack management experience, do not delegate, and have poor communication skills.

\subsubsection{The relevance of finance and financial skills to the business}

Without sufficient finance, a business cannot take advantage of opportunities in the market. The entrepreneur will need capital to cover the overall fixed assets, remunerate and train staff, create brand awareness, and continue operations (Barringer \& Ireland, 2010). He/she will need to raise capital, attract investors and endeavour to obtain the right amount of capital need for the business's operations, viability and growth (Wickham, 2004). According to Nieman and Nieuwenhuizen (2009),financerefers to cash or any resource that can be easily converted into cash, and 
may originate from different sources, not limited to the entrepreneur's own invested money, investors' capital, lenders, business incomes, government support programmes, or other money acquired from different partnership or contracts. However, creditors' money often carries some debt risks, which if not properly managed, may lead to business bankruptcy (Barringer \& Ireland, 2010).

In spite of fear of the failure, many small business owners tend to start the business with insufficient capital, andget stagnantat the start-up phase or fail due to cash flow shortages. Hence, Barringer and Ireland (2010), note that financial reasons are central to the failure of a number of new business start-ups.

\subsubsection{Financial management skills and business}

Financial management skillsrefer to the ability to manage and control cash flow (Venter, Urban, \& Rwigema, 2008). According to Arasti (2011), in today's trading environment, businesses that lack the abilityto master and manage financial accounting skills may not survive in the market. As viewed above,financial accounting skills become crucial for small business managers.According to Flynn, Koornhof, Kleynhans, Meyer and Posthumus (2005), the basic requirements in this function include but are not limited to the following: preparing the operational budgets and to ensure that transactions are accurately recorded; giving approval for all transactional expenditures and reporting the financial transactions; and providing financial guidance and support to management decision making.Small business managers also need the ability to manage other people's money (credit)and complywith tax regulations as per governmentbecause if not, they can bankrupt a business (Frynas \&Mellahi, 2011).

\subsubsection{Cash flow troubles}

Cash flow problems signal eminentbusiness failure. Some of the problems include extensive creditor's days that may cause shortage of operational capital, bad debts, and stock turnover (Nieman \& Nieuwenhuizen, 2009). Although a negative cash flow iscommonly acceptable at the initial phase of the business (due to high associated costsof start-up equipment, training employees, etc.) it often leads to business failure when prolonged(Barringer \& Ireland, 2010).

\subsubsection{Creditors and business failure}

According to Flynn et al. (2005), creditors are people or entities that lend capital to entrepreneur's venture with the expectation of the loan repaid, with interest,within a fixed time period. Due to the fact that their money is at risk,creditorsare stringent and the main focus is on the ability of the business to pay its debts in cash on the due date (Flynn et al. 2005). To reduce risks, creditors would likely want to be on the board of advisers to businesses in which they have invested in large sums of money (Barringer \& 
Ireland, 2010). However, if the business fails to repay the monthly loan repayments, as agreed, investors can bankrupt a business (Dimitras, Zanakis \& Zopounidis, 1996; Nieman \& Nieuwenhuizen, 2009; Barringer \& Ireland, 2010).

\section{Research methodology}

Marvasti (2004)and Bhattacherjee (2012) define social science as the "reexamination" of human social interrelation with other groups, businesses, organisations, macroeconomic activities and the way they behave, using scientific techniques to discover, comprehend and clarify issues that have impact on the society. As a social research, this study was conducted under the positivism theoretical perspective. From a positivist perspective, this study is aligned to a system with a series of actions that has been explored as well as statutes that should be reviewed, understood and explained independently and objectively (Marvasti, 2004).

The fact that positivism relates reasoning and oriented direction with the quantitative approach,a relationship should be possible between them as they strive to postulate what social research is. As a result, the research was anchored on the quantitative method and the questionnaire was utilsed as the primary data collection instrument. Brynard and Hankom (2006) claim that the quantitative method is supported by a clear hypothesis that "should pass as warrantable knowledge" for respondents.

\subsection{Data collection instrument}

According to Kothari (2004) a questionnaire is the means of collecting identical data from a significant number of people by using a unique technique, where the result is later analysed in a systematic manner. Hence, a questionnaire was utilised to gather data for the empirical study. It was designed under nominal and ordinal scales of measurement. It is important to point out that the questionnaire allowed the researcher to approach as many respondents as possible.Furthermore, it also allowed the researcher to reduce discrepancies in the interpretation of data, and minimise some costs of materials, and save time (Sarantakos, 1998:224; Denscombe, 2007). This notwithstanding, the questionnaire can also be disadvantageous, because biased responses are possible as a result of lack of supervision (Sarantakos, 1998).

\subsection{Targetpopulation}

Brynard and Hankom (2006) argue that population denotes a number of subjects with exact characteristics and attributes, which consequently symbolize the researcher's target population. The target population of this study was the small enterprises operating in the municipal area of Viana in the Luanda province in Angola. The municipal area of Viana was selected from the seven municipalities in the Luanda province because of the considerably high visibility and diversification of small businesses in that area, and 
because it is the most industrialised and growing municipality. Small businesses in this study are defined by the number of employees being between 11 and 100 and/ or by an annual revenue of greater than USD 250000 and equal to or less than USD 3 million (Angola, Diário da República, 2011).

\subsection{Sampling design}

Sampling is the process of separating a significant portion of the population by taking into account the limitations and characteristics that denote them, in order to represent the population (Coldwell \& Herbst, 2004). According to Sarantakos (1998), two types of sampling techniques are available, probability sampling, which ensures that every individual in the population has an equal opportunity of being selected for the sample, and non-probability sampling, where it is left to the researcher to decide what sample to use for the study.

Due to the absence of a represented list of businesses to draw from, the paper adopted the snowball sampling technique (non-probability) to draw the sample. According to Denscombe (2007) snowball sampling involves the building of sample size through a line of references, from one respondent to another. By benching marking with four recently conducted related studies (Tengeh, 2011), a sample size of 130 was deemed suitable for the study. The analysis of the empirical study was effectuated on the base of 108 returned questionnaires.

\subsection{Data collection and analysis}

The data for the study was collected in the municipal area of Viana in the province of Luanda, Angola, from managers and business owners who have experienced business failure. From the 130 questionnaires distributed, 117 were returned, and only 108 were processed for analysis, given that nine questionnaires were unusable due to physical damage and inadequately filled out by respondents.

The Statistical Package for the Social Sciences (SPSS) software was used to analyse the primary datacollected. According to Kulas (2009), the SPSS can carry out diverse statistical analyses, both descriptive and inferential. The purpose of using the SPSS software was to allow forthe manipulation of each variable into descriptive statistics. The variables were stored under two levels of measurement, nominal and ordinal levels, which resulted in the data reported in frequencies, percentages and illustrated in tables.

\section{Presentation and discussion of findings}

In this section, the results of the analysis are presented and discussed. The results were reported in frequencies, tables and figures, andare broadly discussedand aligned to the main questions that underpinthis paper. This section is thus, presented under the 
following themes: business profile, managerial andthe financial perspectives of business failure.

\subsection{Business profile}

The purpose of this section was to collect data that ascertain the distinctive characteristics of the failed businesses in municipal area of Viana. The resultsin figure 1 ,indicate that the range from 11 to 50 employees represented $86.1 \%$ of the failed businesses, and the range from 51 to 100 represented10.5\%. Bothranges fall into the category of small business in Angola, while the other group fall on the category of micro business, which range from 1 to 10 and represent $3.4 \%$ of the total.Similarly, studies by Singer, Amorós, Arreola and GERA (2015) found that within the Southern African countries like South Africa, Namibia and Angola who have a less number of entrepreneurs $(4.5 \%, 3.1 \%$, and $6.1 \%$ correspondingly) that employ twenty people and above.

\section{Figure - 1: Category of the failed business}

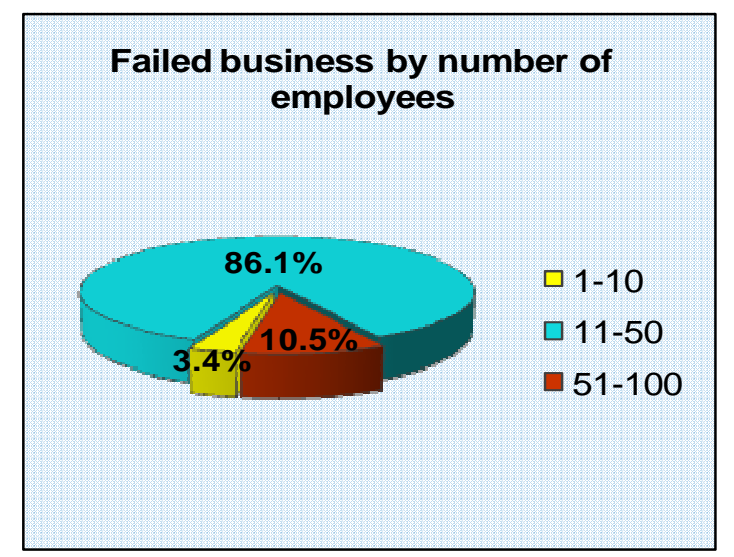

Figure - 2: Business operating sector

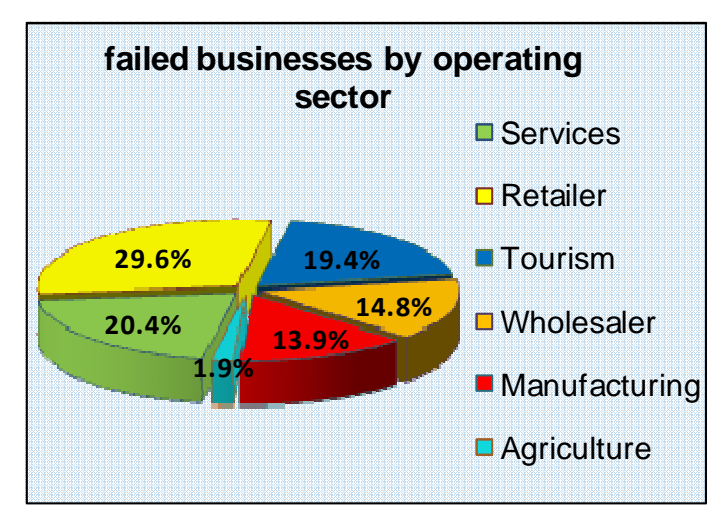

While noting the diversity of the business sector in Angola, it was revealed that nearly one third $(29.6 \%)$ of the failed businesses were retailers (figure 2), while closely 
one quarter $(20.4 \%)$ were services-related businesses, and $14.8 \%$ were wholesalers. The tourism sector represented $19.4 \%$, while $13.9 \%$ were in manufacturing and $1.9 \%$ in agriculture.

\subsection{Managerial perspectiveof business failure}

This section reports on the managerial factors noted to contribute to the failures of MSEs.

\subsubsection{Leadership skills and business failure}

Findings on table 3 indicate that more than two third (69.4\%) of respondents concord that insufficient skills in the domain of leadership is a potential problem that have caused their business to failure, though 30.6 percent of respondents felt unlike. The foregoing concurs with Mahadea and Youngleson's (2013) finding that; lack of effective leadership and the weak general management skills, are all factors that may contribute to the failure of a business.

\subsubsection{Knowledge of business systems}

Table 3 indicates that while nearly three quarters $(71.3 \%)$ of the owner/managers fully agreedthat insufficient knowledge in the domain of businesscaused the business to fail, approximately one quarter $(28.7 \%)$ disagreed. This result is corroborated by Mahamid (2012) who found that insufficient understanding of the business system and lack of management experience are key factors which contribute to business failure. According to Wickham (2004) entrepreneurs should possess the required skills and knowledge to start a business, they must be well informed about the business system and the industry, have a good knowledge of the product or service offered, have management skills and be able to quickly learn new skills as the business might require.

\subsubsection{Management control and work overloaded}

A slightly above two third (68.2\%) of respondents, agreed (table 3) that they lost management control due to work overloaded, while nearly one third (31.8\%) disagreed. This result aligns with Mahamid (2012) who found that work overload due to lack of trust or delegating skills was a common reason for business failure. To be viable, a business requires input from its stakeholders.

\subsubsection{Management and communication skills}

Table 3 shows that nearly three quarters $(74.1 \%)$ of the respondents disagreed thatmanagement's lack of communication skills contributed business failure, while 25.9 percent have agreed. These findings differ from Khalfan (2003) who found that lack of 
communicating essential operating procedures and information was a significant factor which contributed to business failure. Results, suggest that the respondents would pass the right and timely information to employees, as it is crucial for quality tasks accomplishment.

On another note, slightly above half $(53.3 \%)$ of respondents fully agreed that lack of ineffective communication with the external stakeholders could cause the business to fail. However, nearly half (46.7\%) of respondents disagreed with thestatement. A similar study conducted in Belgium by Ooghe and Prijcker (2008) found that some factors which contributed to failure were unsatisfied customers and suppliers and banks which lost trust in the business. This emphasises the fact that good business communication with customers, suppliers and lenders is crucial for any business to be successful and sustainable.

\subsubsection{Business management experiences}

The findings with regards to management experience (Table 3) ascertained that nearly two third $(66.4 \%)$ of respondents agreed that this factor influenced their businesses to failure, and slightly above one third (33.6\%) disagreed. Similarly, Mahamid (2012) found this factor to be a pertinent influencer of business failure.

\subsubsection{Quality of products offered}

Results indicate that $52.9 \%$ of the respondents suggested that the poor quality of their products is a pertinent factor which contributed to the failure of their business. According to Ooghe and Prijcker (2008), Arasti (2011) and Strydom (2011) a business which neglects to supply superior product or service will lag behind its competitors and fail. Wickham (2004) maintains that the product or service to be offered by a small business should be of value to fill a gap in the marketplace, and be able to compete effectively with large companies that offer similar products.

Table - 3: Failure factors regarding respondents management competencies

\begin{tabular}{|c|c|c|}
\hline \multirow{2}{*}{ Variables } & \multicolumn{2}{|c|}{ Total Valid percentage } \\
\hline & Agreed & Disagreed \\
\hline Insufficient skills in the domain of leadership & 69.4 & 30.6 \\
\hline Lack of knowledge in the domain of business system & 71.3 & 28.7 \\
\hline Loss of management control due to work overloaded & 68.2 & 31.8 \\
\hline Lack of management internal communication skills & 25.9 & 74.1 \\
\hline Lack of effective communication with external stakeholders & 53.3 & 46.7 \\
\hline Insufficient business management experiences & 66.4 & 33.6 \\
\hline
\end{tabular}




$\begin{array}{lcc}\text { poor quality of the offers } & 52.9 & 47.1 \\ \text { Absence of a professional advice } & 60.2 & 39.8 \\ \text { Poor price settlement for the business strategic position } & 24.6 & 75.4 \\ \text { High uncontrolled expenses as a cause of failure } & 74.8 & 25.2 \\ \text { Failure to fulfill monthly lenders obligations } & 37.4 & 62.6 \\ \text { Lengthy cash conversion period } & 53.7 & 46.3 \\ \text { Failure to comply with due tax } & 23.2 & 36.8 \\ \text { Lack of marketing planning } & 69.1 & 30.9 \\ \text { Lack of financial plan } & 78.7 & 21.3 \\ \text { Failure to effectively control business asset } & 72 & 28\end{array}$

\subsubsection{The need for professional advice}

Table 3 above also reveals that a total of $60.2 \%$ of the respondents agreed that lack of professional advice caused their business to fail, while $39.8 \%$ disagreed with this notion. These findings indicate that the majority of respondents felt that the absence of advice from business experts contributed to their business failure. Several authors opine that access to consultants who can provide expert professional advice is crucial for business continuation (Da Rocha, 2011; Mendes, 2012; Herrington, 2014). Barringer and Ireland (2010) posit that the role of professional business consultants is important as they could assist the entrepreneur to resolve difficult issues pertaining to the business's viability.

\subsubsection{Pricing Strategy and business failure}

Price is the money the customers have to pay for the product (Barringer \& Ireland, 2010). The price set for a good or service may determine the amount that would be bought by customers. In some cases, high prices may deter customers while the reverse is true. Nieman and Nieuwenhuizen (2009) observe that if the price is set too high, or to low the demand for the product may suffer depending on the target market.

Table 3, depicts the participants' responses regarding the low or high price strategy as a contributor to business failure. It was noted that nearly three quarters (74.4\%) of the respondentsare in disagreement that poor pricing strategy contributed to the failure of their businesses, and closely one quarter $(24.6 \%)$ of them observed the reverse. Small business managers should not neglect the importance to seriously considering the suitable price strategy, as customers are too sensitive to this factor. 


\subsubsection{Expenses and business failure}

Approximately seventy-five percent $(74.8 \%)$ of the respondents agreed (Table 3 ) that excessively high uncontrolled expenses contributed to the failure of their businesses, and $25.2 \%$ discord with this factor. According to Barringer and Ireland (2010) small business managers and owners' negligence to analyse the effects of all the outgoing capital can be disastrous for the business.

\subsubsection{Meeting monthly lenders' obligations and business failure}

Table 3 indicates that 62.6 percent of respondentsdisagreed, and 37.4 percent agreed that escaping to pay lenders on a monthly base hascaused their businesses failure.Several authors Dimitras, Zanakis and Zopounidis (1996); Nieman and Nieuwenhuizen (2009); and Holt (2013), sustain the money lent from lenders or products received in credit do carry some debt risks and the failure to fulfil with obligations can take the business to bankruptcy.

\subsubsection{Cash conversion period and business failure}

With regards to the delays to convert goods to cash, the table 3 indicates that slightly above half $(53.7 \%)$ of respondents in Viana fully agreed that they have experienced failure due to the retention of goods in store for a long period, while 46.3 percent fully disagreed.

\subsubsection{Tax matters and business}

Results (Table 3) further indicate that $76.8 \%$ of respondents disagreed that noncompliance with government tax regulations was the cause of their business failure, while $23.2 \%$ agreed this notion. Stiglingh, Koekemoer, van Schalkwyk, Wilcocks, de Swardt and Jordaan (2011) posit that tax avoidance can result in high costs to the business, imposed as penalties or to a business being closed down by the relevant tax authorities. Good business management involves complying with the government regulations such as payment of tax and basic conditions of employment.

\subsubsection{Marketing plan and business failure}

Table 3 indicates that slightly above two third (69.1\%) ofrespondents agreed,while closely one third (30.9\%) disagreed that the lack of a proper marketing plan impacted negatively on their business. Failure to conduct a marketing plan may affect the business's position in the market through its effect on product quality, price, promotion, sales and distribution (Barringer \& Ireland, 2010).Lack thereof, may also impact on the availability of customers, raw material, competitors, and human resources. 


\subsubsection{Financial plan and business failure}

Thefindings further indicate that more than three quarters $(78.7 \%)$ of respondents, are of the agreement that the nonexistence of a financial plan for their businesses have caused them to fail, while less than one quarter (21.3\%) disagree. These results are corroborated by Barringer and Ireland (2010) and Youngleson (2013) who found that neglecting to monitor and effectively manage business resources and budgets to ensure a sustainable business turnover is one of the primary reasons many businesses fail.The above results suggest that the respondents neglected to develop a sound financial plan, which would have ensured that resources were efficiently managed to meet the overall business expenses.

\subsubsection{Control of business assets and failure}

The findings on Table 3, indicates that nearly three quarters $(72 \%)$ of business owners/managers in Viana, agreed that less control of the business's resources (i.e. raw material or finished product, equipment and employees) influenced on the business failure, while the other 28 percent respondents disagreed.

\subsection{Financial skills and business failure}

Finance remains a compulsory source for business operations and continuity. One of the focuses of this paper was also to assess the impact ofmanagers' financial skills onsmall business failure in the municipality of Viana in Angola.

\subsubsection{Financial accounting and business failure}

It was found that more than three quarters $(80.6 \%)$ of owners/managers agreed that insufficient skills in the domain of financial accountingcaused their businesses to failure, while 19.4\% disagreed. Similarly, Arasti (2011) ascertained that the manager'sinability to master and manage financial resources may lead to business failure.

\subsubsection{Recording financial transactions and business failure}

This study ascertained that more than three quarters (79.6\%) of respondents agreed that absence of cash flow record influenced their businesses to failure, while 20.4 percentare of disagreement. However, signs of failure can be found through exposure of an accurate financial transaction recordand thorough analysis if any problem exists. 


\subsubsection{Cash flow and business failure}

The resultsin Table 4, indicate that nearlytwo third(63.9\%) of respondents disagreed and slightly above one third (36.1\%) agreed that they have experienced a shortage of cash due to irrecoverable customers' debts.However, an extensive effort by the part of owner/manager is always needed to obtain payment from debtors in order to avoid shortage of cash flow.

Table - 4: Failure factors regarding owner/managers financial skills

\begin{tabular}{|l|c|c|}
\hline \multicolumn{1}{|c|}{ Variables } & \multicolumn{2}{|c|}{ Total valid percentage } \\
\cline { 2 - 3 } & \multicolumn{1}{|c|}{ Agrees } & 19.4 \\
\hline Insufficient skills in the domain of financial accounting & 80.6 & 20.4 \\
Lack of recording the financial transactions & 79.6 & 63.9 \\
Customers' failure to pay debts & 36.1 & 39.8 \\
Cash flow problems on start-up stage & 60.2 & 28 \\
Using a unique bank account for business and personal & 72 & 13.9 \\
Delays in collecting credit from customers & 86.1 \\
\hline
\end{tabular}

\subsubsection{Start-up capital and business failure}

The findings noted in Table 4, indicate that closely two third $(60.2 \%)$ of respondents in are in agreement that utilising limited capital at the start-up stage contributed to the failure of their businesses, while 39.8 percent disagreed. According to Barringer and Ireland (2010) earlier stage shortage of money for business operations is one of the key factors that have contributed to the failure of a number of new businessstart-ups. This would justify the heavy costs that entrepreneurs experience on the initial phase for the overall fixed assets, staff train, brand awareness, and the negative cash flow (Barringer \& Ireland, 2010).

\subsubsection{Bank account and business failure}

With regards to owners/managers using a unique bank account for business and personal needs,the findings indicated thatnearly three quarters $(72 \%)$ of respondents agreed that this factorcontributed significantly to the failure of their businesses, while closely to one third (28\%) disagree.Monitoring a business's bank account requires great responsibility, so that business can grow in its assets. 


\subsubsection{Debt collection and business failure}

The research results indicate that more than three-quarters $(86.1 \%)$ of respondentsare indisagreement,and 13.9 percent agreedthat negligence in collecting credit (especially on time) impacted negativelyon their businesses. According to Flynn et al. (2005) the length of credit terms should be between 30 to 90 days, and customer accounts extended beyond such terms can bring complex cash flow problems to a small business.

\section{Conclusion}

This study was initiated to investigate the managerial and financial factors the contributed to failure of MSEs in the Viana municipality in Luanda, Angola. Thestudyrevealed that, insufficient skills in the domain of financial accounting (80.6\%), backed with negligence to budgeting (financial plan 78.7\%) and record keeping of financial transactions (79.6\%)are critical failure factors.Having a spiral effect, the just mentioned factors prevented the managers/ownersfrom utilising the possessed resources effectively; analysing the outgoing capital;calculating risk; and identifying eminent failure signals. Other compellingfactors included insufficient knowledge in the domain of the business systems (71.3\%); lack of previous experience (66.4\%);failure to handle the business bank account as own personal account (72\%), andinsufficientskills in the domain of leadership (69.4\%). Again the latter results were seen to spiral into other deficiencies such as work overload $(68.2 \%)$ resulting from non- delegation; insufficient control of business resources $(72 \%)$; high operating costs $(74.8 \%)$, and lack of marketing knowledge and planning $(69.1 \%)$.

\section{References}

1. Altman, E.I., Narayanan, P. (1997) An international survey of business failure classification models. Financial Markets, Institutions \& Instruments, 6(2), May.

2. Altman, E.I. (1984) The success of business failure prediction models: an international survey. Journal of Banking and Finance, 8,171-198.

3. Amorós, J.E., Bosma, N. (2014) Global Entrepreneurship Monitor 2013 global report: fifteen years of assessing entrepreneurship across the globe.

4. Angola Press Agency (Angop). (2013) Baixa taxa de sucesso do empreendedorismo tem a ver com constrangimentos económicos. http://www.portalangop.co.ao/angola/pt_pt/noticias/economia/2013/6/29/Baixa-taxasucesso-empreendedorismo-tem-ver-com-constrangimentos-economicos,30a296c49adc-45d3-9918-e125cdd4d365.html [5 May 2014].

5. Angola, Diário da República (2012) Decreto Presidencial N. ${ }^{\circ} 40 / 12,13$ de Março. Diário da República: 1(49):1143-1158, 13 March.

6. Angola, Diário da República. (2011) Lei n. ${ }^{\circ}$ 30/11 de 13 de Setembro, Lei das Micro, Pequenas and Medias Empresas. Diário da República: 1(176):4294-4301, Setembro 2.

7. Angola MINEC. (2013) Primeiro ano dos mecanismos de financiamento do programa Angola investe. http://www.minec.gov.ao/VerNoticia.aspx?id=19021 [10 May 2014]. 
8. Angola, Ministerio da Economia (MINEC). (2012) Programa de desenvolvimento das síntese do programa. http://www.minec.gov.ao/VerPublicacao.aspx?id=820 [27 April 2014].

Angonotícias. (2013). Só 3 em cada 100 empresas criadas em Angola sobrevivem. http://www.angonoticias.com/Artigos/item/39259/so-3-em-cada-100-empresas-criadasem-angola-sobrevivem [5 May 2014].

9. Arasti, Z. (2011). An empirical study on the causes of business failure in Iranian context. African Journal of Business Management, 5(17):7488-7498, September.

10. Barringer, B.R., Ireland, R.D. (2010). Entrepreneurship: Successfully launching new ventures. 3 ed. New Jersey: Pearson.

11. Bhattacherjee, A. (2005) Models of Firm Dynamics and the Hazard Rate of Exits: Reconciling Theory and Evidence using Hazard Regression Models. http://128.118.178.162/eps/em/papers/0503/0503021.pdf [27 June 2014].

12. Bhattacherjee, A. (2012) Social science research: principles, methods and practices. University of South Florida. Florida. http://scholarcommons.usf.edu/cgi/viewcontent.cgi?article=1002\&context=oa_textbook s [18 September 2014].

13. Bosma, N., Acs, Z.J., Autio, E., Coduras, A., Levie, J. (2009) Global Entrepreneurship Monitor (GEM) 2008: executive report. Global reported.

14. Brynard, P.A., Hankom, S.X. (2006) Introduction to the research in managementrelated fields. 2nd Ed. Pretoria: Van Schaik.

15. Cant, M.C., Wiid, J.A. (2013) Establishing the challenges affecting South African SMEs. International Business \& Economics Research Journal, 12(6):707-716, June.

16. Clark, M., Eaton, M., Lind, W., Pye, E., Bateman, L. (2011) Australia Small businesses key statistics. Australian Government: Department of Innovation, Industry, Science and Research. http://workspace.unpan.org/sites/internet/Documents/UNPAN92675.pdf [23 May 2014].

17. Coldwell, D. \& Herbst, F. 2004. Business Research. Cape Town: Juta.

18. Cox, D.R. 1972. Regression Models and Life-Tables. Journal of the Royal Statistical Society, 34(2):187-220.

19. Cronje, G.J., du Toit, G.S., Motlatla, M.D.C (2000) Introduction to business management. 5th ed. Oxford: OUP.

20. Cronje, G.J., du Toit, G.S., de K Marais, A., Motlatla, M.D.C.. (2004). Introduction to business management. 6th ed. Oxford: OUP.

21. Da Rocha, M.J.A. (2011) Estabilização, reforma e Desenvolvimento em Angola. 2nd ed. Luanda: Mayamba.

22. Dasgupta, S., Sanyal, D. (2010) A stitch in time saves nine: behind every major business failure lies an untold story. Business strategy series, 11(2):100-106.

23. Davis, S.J., Haltiwanger, J., Schuh, S. (1994). Small Business and Job Creation: Dissecting the Myth and Reassessing the Facts. Business Economics, 29(3):13-21, July.

24. Denscombe, M. (2007). The good research guide: for small-scale social research projects. 3rd ed. New York: McGraw Hill.

25. Di Pietro, W., Sawhney, B. (1977) Business Failures, Management Competence, and Macroeconomic Variables. American Journal of Small Business, 2(2):4-15, October.

26. Dias, J. (2013). O papel das pequenas empresas na economia. Jornal de Angola. http://jornaldeangola.sapo.ao/reportagem/o_papel_das_pequenas_empresas_na_econom ia [23 May 2014].

27. Dimitras, A.I., Zanakis, S.H, Zopounidis, C. (19960 A survey of business failures with an emphasis on prediction methods and industrial applications. European Journal of Operational Research, 90:487-513.

28. Flynn, D., Koornhof, C., Kleynhans, K., Meyer, L., Posthumus, L. (2005) Fundamental accounting. 5th ad. Cape Town: Juta.

29. Frynas, J.G, \& Mellahi, K. (2011) Global strategic management. 2nd ed. New York: OUP. 
30. Greener, S. (2008) Business research methods. Ventus publishing. http://kosalmath.files.wordpress.com/2010/08/introduction-to-research-methods.pdf [19 September 2014].

31. Hendrikse, J., Hendrikse, L. (2004) Business governance handbook: principle and practices. Cape Town: Juta.

32. Herrington, M. (2014) GEM 2012 Sub-Saharan Africa Regional Report - Policy Insights. April. http://www.gemconsortium.org/docs/download/3337 [15 May 2014].

33. Holt, G.D. (2013). Construction business failure: conceptual synthesis of causal agents. Construction Innovation, 13(1):50-76.

34. Honjo, Y. (2000). Business failure of new firms: an empirical analysis using a multiplicative hazards model. International Journal of Industrial Organization, 18:557574.

35. Ihua, U.B. 2009. SMEs key failure-factors a comparison between the United Kingdom and Nigeria. J SocSci, 18(3):199-207.

36. Khalfan, A. (2003). A case analysis of business process outsourcing project failure profile and implementation problems in a large organisation of a developing nation. Business Process Management Journal, 9(6):745-759.

37. Kothari, (2004). Research Methodology: Method and Techniques. 2nd ed. New Delhi: New Age International.

38. Kulas, J.T. (2009). SPSS essentials: Managing and analyzing social sciences data. San Francisco: Jossey Bass.

39. Lane, W.R., Looney, S.W., Wansley, J.W. (1986) An application of the Cox proportional hazards model to bank failure. Journal of Banking and Finance, 10:511531.

40. Mahadea, D., Youngleson, J. (2013). Entrepreneurship and small business management. Cape Town: Philippa Van Aardt.

41. Mahamid, I. (2012) Factors affecting contractor's business failure: contractors' perspective. Engineering, Construction and Architectural Management, 19(3)269-285.

42. Marvasti, A.B. (2004) Qualitative research in sociology: an introduction. London: Sage. http://swauop.yolasite.com/resources/qualitative\%20research\%20in\%20sociology_3.pd f [19 September 2014].

43. Mead, D.C., Liedholm, C. (1998). The Dynamics of Micro and Small Enterprises in Developing Countries. World Development, 26(1):61-74.

44. Mendes, A.I.M. (2012) Empreendedorismo e Crescimento Económico - o caso de Angola. Dissertação de Mestrado, Universidade do Minho Escola de Economia e Gestão, Luanda.

45. Molina, C.A. (2002) Predicting bank failures using a hazard model: the Venezuelan banking crisis. Emerging Markets Review, 3:31-50.

46. Nemaenzhe, P.P. (2010) Retrospective analysis of failure causes in South African small businesses. Un published $\mathrm{PhD}$ Thesis, University of Pretoria, Pretoria.

47. Nichter, S., Goldmark, L. (2009) Small Firm Growth in Developing Countries. World Development, 37(9):1453-1464.

48. Nieman, G., Nieuwenhuizen, C. ( 2009) Entrepreneurship: A South African perspective. 2nd ed. Pretoria: Van Schaik.

49. Ooghe, H. , Prijcker, S.D. (2008) Failure processes and causes of company bankruptcy: a typology. Management Decision, 46(2):223-242.

50. Pratten, J.D. (2004). Examining the possible causes of business failure in British public houses. International Journal of Contemporary Hospitality Management, 16(4):246252.

51. Preisendorfer, P., Voss, T. (1990). Organizational Mortality of Small Firms: The Effects of Entrepreneurial Age and Human Capital. Organization Studies, 11(1):107-129.

52. Sarantakos, S. (1998) Social research. 2nd ed. South Yarra: Macmillan Education.

53. Shumway, T. (2001) Forecasting bankruptcy more accurately: A simple hazard model. The Journal of Business, 74(1):101-124, January. 
54. Singer, S., Amorós, J.E. , Arreola, D.M. (2015). Global Entrepreneurship Monitor 2014 Global Report. ISBN: 978-1-939242-05-1. http://gemconsortium.org/report [25 May 2015].

55. Singh, G., Belwal, R. (2008). Entrepreneurship and SMEs in Ethiopia: Evaluating the role, prospects and problems faced by women in this emergent sector. Gender in Management: An International Journal, 23(2):120-136.

56. Stiglingh, M., Koekemoer, A.D., van Schalkiwyk, L., Wilcocks, J.S., de Swardt, R.D. , Jordaan, K. (2011) Silke: South African income Tax. Durban: LexisNexis.

57. Strydom, J. (2011). Principles of business management. 2nd ed. Cape Town: Oxford.

58. Tengeh, R.K. (2011) A business framework for the effective start-up and operation of African immigrant-owned businesses in the Cape Town Metropolitan area, South Africa. Unpublished PhD thesis, Cape Peninsula University of Technology, Cape Town.

59. The USA Small Business Administration (SBA), Office of Advocacy, (2012) Frequently Asked Questions about Small Business. http://www.sba.gov/sites/default/files/FAQ_March_2014_0.pdf [15 June 2014]

60. Venter, R., Urban, B., Rwigema, H. (2008) Entrepreneurship: theory in practice. 2nd ed. OUP Southern Africa: Cape Town.

61. Wickham, P.A. (2004) Strategic entrepreneurship. 3rd ed. Harlow: Prentice Hall or Pearson Education.

62. WorldBank. (2014) Angola Overview. http://www.worldbank.org/en/country/angola/overview [20th April 2014].

63. Yeo, K.T. (2002) Critical failure factors in information system projects. International Journal of Project Management, 20:241-246.

64. Yin, R.K. (2011) Qualitative research from start to finish. New York: The Guilford Press.

http://doha.ac.mu/ebooks/Research\%20Methods/QualitativeResearch_2011_Robert_Yi n.pdf [19 September 2014].

65. Zinga, A.C., Coelho, A.F.M., Carvalho, F.M.P. (2013) Clustering of Angolan entrepreneurs: an analysis of their entrepreneurial posture. Int Entrep Manag J, 9:483500 .

\begin{abstract}
Apstrakt
Dobro je poznato da jedan broj faktora nesrazmerno doprinosi neuspehu mikro i malih preduzeća u većini privreda. Ovaj rad ispituje menadžerske i finansijske faktore koji doprinose neuspehu malih i srednjih preduzeća u Angoli. Rad je usvojio pozitivističkoteoretsku perspektivu koristeći se upitnikom za prikupljanje podataka kao primarnim instrumentom kvantitativne tehnike istraživanja. Podaci su prikupljeni od 108 vlasnika $i$ menadžera malog biznisa koji su imali iskustvo poslovnog neuspeha. Podaci su analizirani uz pomoć statističkog paketa za društvene nauke (SPSS). Rezultati su utvrdili da su nedovoljno znanje iz oblasti poslovnih sistema, nedovoljne sposobnosti u domenu finansijskog računovodstva $i$ namera planiranja $i$ kontrole poslovne resurse, bili među faktorima koji su doprineli neuspehu malih i srednjih preduzeća u Angoli. Ovo ukazuje na nedostatak aktivnosti institucija u promociji preduzetništva, nedostatak u znanju i razvoju veština $i$ odsustva uspešnih preduzetničkih uzora, poslovnih mentora ili trenera za izgradnju preduzetničkih kapaciteta.
\end{abstract}

Ključne reči: neuspeh malog biznisa, faktor neuspeha, poslovno okruženje, preduzetnik, Angola 